\title{
Growth hormone improves lipoprotein concentration and arylesterase activity in mice with an atherogenic lipid profile induced by lactalbumin
}

\author{
Elvira López-Oliva ${ }^{1}$, Meritxell Nus ${ }^{2}$, Angel Agis-Torres ${ }^{1}$, Wilma Villaro ${ }^{1}$, José M. Sánchez-Montero ${ }^{3}$, \\ Emilia Muñoz-Martínez ${ }^{1}$ and Francisco J. Sánchez-Muniz ${ }^{2 *}$ \\ ${ }^{1}$ Sección Departamental de Fisiología Animal, Facultad de Farmacia, Universidad Complutense de Madrid, Madrid, Spain \\ ${ }^{2}$ Departamento de Nutrición y Bromatología I (Nutrición), Facultad de Farmacia, Universidad Complutense de Madrid, \\ Madrid, Spain \\ ${ }^{3}$ Biotransformations Group, Departamento de Química Orgánica y Farmacéutica, Facultad de Farmacia, Universidad \\ Complutense de Madrid, Madrid, Spain
}

(Received 17 January 2008 - Revised 8 April 2008 - Accepted 18 April 2008 - First published online 1 July 2008)

\begin{abstract}
The effect of growth hormone (GH) on arylesterase (AE), one of the activities of paraoxonase, has never been studied. The aims of the present study in mice were: (a) to compare the effect of age and sex on serum lipid and lipoprotein levels after consumption of lactalbumin- $v$. chow-based diets and (b) to study the effect of GH administration, age and sex on serum AE activity, lipid and lipoprotein and body fat levels in mice fed a lactalbumin diet. Seventy-two mice were divided into three age- and sex-matched experimental groups: (1) control chow (CC), (2) non-GH lactalbumin (NGL) and (3) GH-treated lactalbumin (GL) mice. Lactalbumin increased total cholesterol, (LDL + VLDL)-cholesterol and TAG and diminished HDL-cholesterol in all animals $(P<0 \cdot 05)$. In comparison with their NGL counterparts, old GL males presented lower total cholesterol $(15 \%)$ and $(\mathrm{LDL}+\mathrm{VLDL})$-cholesterol $(17 \%)$ levels $(P<0.05)$, whereas values of the same parameters were higher in adult GL males $(P<0.05)$ (22 and $23 \%$, respectively). Adult GL females displayed higher serum HDL-cholesterol concentrations $(26 \%)(P<0.05)$ than adult NGL females. AE activity was lower in old GL females $(78 \%)$ and old GL males $(20 \%)(P<0.05)$, but higher in adult GL males $(100 \%)$ $(P<0 \cdot 01) . \mathrm{GH}$, that was inversely related to food intake, decreased abdominal and gonadal fat in all mice $(P<0 \cdot 05)$. To conclude, lactalbumin induced an atherogenic lipoprotein profile in NGL mice that was reverted by GH, preferentially in old males, suggesting that GH therapy will be more effective in aged men. The present results suggest that AE activity was age-, sex- and body fat level-dependent and that it diminished as a consequence of improved antioxidant status.
\end{abstract}

Ageing: Arylesterase: Body fat deposits: Growth hormone: Lactalbumin: Lipoproteins

The effect of dietary protein on lipid metabolism and atherosclerosis has been extensively tested ${ }^{(1,2)}$. Most of the studies have compared the effect of casein and soya proteins in young animal models (mainly rabbits and rats) ${ }^{(3,4)}$, while only a few have been performed in adult mice and no information is available for old mice ${ }^{(5)}$. It has been suggested that lactalbumin is the most atherogenic animal protein in rabbits ${ }^{(3)}$, though no data are available for adult and old mice.

The BALB/c mouse strain has been widely used to study the effect of atherogenic diets ${ }^{(6)}$ and has also been used in some growth hormone $(\mathrm{GH})$ studies ${ }^{(7)}$. GH is known to exert important regulatory effects on cholesterol metabolism in mice ${ }^{(8)}$. Both decreased production and increased production of $\mathrm{GH}$ have been associated with increased frequency of $\mathrm{CVD}^{(8)}$. GH treatment in hypophysectomised LDL-receptordeficient mice decreased total cholesterol (TC) and LDLcholesterol levels ${ }^{(7)}$. Transgenic mice overexpressing GH show high TC and LDL-cholesterol concentrations and low TAG levels ${ }^{(9)}$. The effects of $\mathrm{GH}$ treatment on lipoproteins in mice with normal GH secretion have not been studied previously.

The age-related decline in pituitary GH secretion has been linked to many alterations associated with ageing ${ }^{(10)}$ such as fat deposition and detrimental alterations in lipoprotein metabolism and lipid peroxidation impairments. Total-body and abdominal obesity are known to be risk factors of increased CVD morbidity and mortality ${ }^{(11)}$. It has been established that GH can increase lean body mass and reduce adipose tissue mass in elderly subjects and obese animal models ${ }^{(12-14)}$. Results of $\mathrm{GH}$ administration on lipoprotein metabolism in healthy and elderly individuals have been contradictory ${ }^{(15,16)}$ and its use has also produced many side effects, including insulin resistance and probably diabetes ${ }^{(12)}$. Furthermore, sex hormones affect the results of $\mathrm{GH}$ administration differently in males and females $^{(17)}$.

Although the mechanisms underlying the ageing process are poorly understood, forms of DNA, proteins and lipids altered by oxidation found in aged organisms support the hypothesis

Abbreviations: AE, arylesterase; CC, control chow; GH, growth hormone; GL, GH-treated lactalbumin; NGL, non-GH lactalbumin; TC, total cholesterol. * Corresponding author: Professor Francisco J. Sánchez-Muniz, fax +349139418 10, email frasan@farm.ucm.es 
that an increased oxidative status may be associated with ageing $^{(18)}$. Epidemiological studies in GH-deficient subjects $^{(19)}$ and GH-transgenic mice ${ }^{(20)}$ indicate that these animals display reduced expression and/or activity of enzymes involved in antioxidant defences and increased lipid peroxidation. Lipid peroxidation and high LDL-cholesterol serum levels have been known to increase with age, thus putting the elderly at greater risk of atherosclerosis and $\mathrm{CVD}^{(21)}$. It has been suggested that HDL-bound paraoxonase 1 (EC 3.1.1.2), an enzyme that exhibits arylesterase (AE) activity, is involved in lipoprotein-phospholipid metabolism, and could inhibit lipid peroxide generation in $\mathrm{LDL}^{(22,23)}$. Thus, GH treatment of aged animals could improve their antioxidant status by increasing AE activity and helping to maintain a less atherogenic lipoprotein profile. Nonetheless, GH has been reported to inhibit expression of the paraoxonase 1 hepatic gene ${ }^{(24)}$. To the best of our knowledge, the effect of the administration of $\mathrm{GH}$ on AE activity in adult and old mice has never been tested.

The aims of the present study in mice were: (a) to compare the effect of age and sex on serum lipid and lipoproteincholesterol levels after consumption of lactalbumin- $v$. chow-based diets; (b) to study the effect of GH administration, age and sex on serum AE activity, lipid and lipoproteincholesterol and body fat levels in mice fed a lactalbumin diet. Furthermore, the relationships between serum AE activity, serum lipid and lipoprotein-cholesterol concentrations and body fat levels were also tested.

\section{Materials and methods}

\section{Materials}

Recombinant human GH (Norditropin) was donated by Novo Nordisk Pharma S.A. (Madrid, Spain). Control mouse BALB/c serum employed for the AE calibration curves was purchased from Harlan Laboratories (London, UK). Phenylacetate was obtained from Aldrich (Barcelona, Spain). Phenol was purchased from Panreac (Barcelona, Spain) and purified with a glass oven kugelrohr (Büchi, Flawil, Switzerland). All other chemicals and solvents used were of the highest purity commercially available.

\section{Animals and diets}

All procedures were carried out in accordance with the National Institutes of Health guidelines for animal care and experimentation published in the Spanish Royal Order 223/ $88^{(25)}$. The study was approved by the Institutional Committee for the Care and Use of Laboratory Animals of the Universidad Complutense de Madrid, Spain.

$\mathrm{BALB} / \mathrm{c}$ mice were obtained from the breeding centre of Departamentos de Nutrición y Fisiología de la Facultad de Farmacia de la Universidad Complutense (Spanish Government licence: ES280790000085) and maintained at the animal facilities until experimental age. Mice were individually housed in metabolism cages (room temperature $23^{\circ} \mathrm{C} \pm 1{ }^{\circ} \mathrm{C}$ and $12 \mathrm{~h}$ light-dark cycles) and given free access to water and diets.

Seventy-two mice were fed the A04 chow diet (Panlab S. L., Barcelona, Spain) after weaning. The animals were divided into three age- and sex-matched experimental groups at 6 months (adults) and 18 months (old mice) of age. Group 1 contained twenty-four control chow (CC) mice who received a commercial chow diet for mouse maintenance (A04; Panlab, Madrid, Spain) and two subcutaneous injections of saline solution daily (at 08.00 and 17.00 hours) for 1 month. Group 2 was composed of twenty-four non-GH lactalbumin (NGL) mice who were fed a $14 \%$ lactalbumin diet and administered two subcutaneous injections of saline solution daily (at 08.00 and 17.00 hours) for 1 month. Group 3 consisted of twenty-four GH-treated lactalbumin (GL) mice given a $14 \%$ lactalbumin diet and two subcutaneous injections of $2 \mu \mathrm{g} \mathrm{GH} / \mathrm{g}$ body weight daily (at 08.00 and 17.00 hours) for 1 month. Each group included twelve adult (six males and six females) and twelve old (six males and six females) mice. On the last day of the trial, when the mice were 7 and 19 months old, respectively, they were anaesthetised by intraperitoneal injection of ketamine $(100 \mathrm{mg} / \mathrm{kg}$ body weight) plus xylazine $(5 \mathrm{mg} / \mathrm{kg}$ body weight), and blood was drawn via retro-orbital plexus puncture. The mice were euthanised by decapitation. Serum was separated from whole blood by centrifugation $(1500 \mathrm{~g}$; $10 \mathrm{~min} ; 4^{\circ} \mathrm{C}$ ) and stored at $-80^{\circ} \mathrm{C}$ until use.

The main characteristics of the control chow diet were: moisture, $11.9 \%$; crude protein, $16 \cdot 1 \%$; crude oil, $3.1 \%$; crude fibre, $3.9 \%$; $\mathrm{N}$-free extract, $60.0 \%$ (of which starch, $45.8 \%$ and total sugars, $2.0 \%$ ); total minerals, $5.1 \%$; vitamin A, $2 \mathrm{mg}$ (6600 IU)/kg; vitamin $\mathrm{D}_{3}, 22.5 \mu \mathrm{g}$ (900 IU)/kg; vitamin $\mathrm{E}$, $30 \mathrm{mg} / \mathrm{kg}$. The experimental diet containing lactalbumin was formulated according to AIN-93M standards ${ }^{(26)}$, substituting lactalbumin for casein while maintaining all other components (Table 1).

In NGL and GL mice, peri-intestinal, peritoneal and perirenal fat was excised and was referred to as 'abdominal fat'. Periovarian and periepididymal fat pads were cut free and were referred to as 'gonadal fat'. After dissection, fat pads were weighed and frozen at $-80^{\circ} \mathrm{C}$.

\section{Serum measurements}

Serum of all three mice groups (CC, NGL, GL) were analysed for TC, HDL-cholesterol and TAG with enzymic colorimetric commercial kits (Biolabo S.A., Materlab, Madrid, Spain). The estimation of the non-HDL-cholesterol ((LDL + VLDL)-cholesterol) was calculated by the equation: (LDL + VLDL)-cholesterol = TC - HDL-cholesterol. The TC:HDLcholesterol and the (LDL + VLDL)-cholesterol:HDL-cholesterol ratios were employed as cardiovascular risk indexes.

Table 1. Composition of semi-synthetic experimental lactalbumin diet

\begin{tabular}{lc}
\hline Ingredient & Lactalbumin diet $(\mathrm{g} / \mathrm{kg}$ diet $)$ \\
\hline Lactalbumin & 140 \\
Maize starch & $465 \cdot 692$ \\
Dextrinised maize starch & 155 \\
Sucrose & 100 \\
Cellulose & 50 \\
Mineral mix (AIN-93M) & 35 \\
Vitamin mix (AIN-93VX) & 10 \\
L-Cystine & $1 \cdot 50$ \\
L-Arginine & $0 \cdot 70$ \\
Choline bitartrate & $2 \cdot 5$ \\
$t$-Butylhydroquinone & $0 \cdot 0008$ \\
Soyabean oil & 40 \\
\hline
\end{tabular}




\section{Serum arylesterase activity}

Serum AE activity of NGL and GL mice was measured using the method of Nus et al. ${ }^{(27)}$, with simulated body fluid as the buffer and phenylacetate $(0.25 \mathrm{mM})$ as the substrate after adaptation to the mouse model ${ }^{(28)}$. The molar absorption coefficient of phenol, determined spectrophotometrically at $270 \mathrm{~nm}, 25^{\circ} \mathrm{C}$ and $\mathrm{pH} 8$, was $1297 / \mathrm{M}$ per cm. A quantity of 1 unit $\mathrm{AE}$ activity is equal to $1 \mathrm{~mol}$ phenylacetate hydrolysed/litre per min. The AE:HDL-cholesterol ratio was employed as a potential marker of HDL antioxidant capacity.

\section{Statistical analysis}

Data are presented as mean values and standard deviations. Spearman correlation coefficients were used to evaluate the relationships between continuous variables. $\mathrm{CC}$ and NGL mice data were initially evaluated using two-way ANOVA. When significant differences were detected the minimum significant difference (MSD) procedure was used to assess the differences between the groups with a prespecified $P$ value of 0.05. Three-way ANOVA was employed to study the effect of treatment, sex and age. An unpaired Student's $t$ test was employed to analyse the effect of GH treatment, segmenting data by sex and age groups. The Kruskal-Wallis H test was employed to analyse data of TAG and AE activity because they were not distributed normally. Non-parametric multiple comparisons were made using a modification of the Hollander and Wolfe formula by Sánchez et al. ${ }^{(29)}$ using SAS 7.0 statistical software (SAS Institute, Inc., Cary, NC, USA). All statistical analyses were performed using the statistical package SPSS version 15.0 (SPSS Inc., Chicago, IL, USA). Progress curves of the AE reactions were fitted to first-order kinetics using the SIMFIT 5.4 statistical package (Manchester University, Manchester, UK) ${ }^{(30)}$.

\section{Results}

\section{Effect of age, sex, diet and treatment on feed intake}

Fig. 1 shows the feed intake of CC, NGL and GL mice. No significant differences were found for feed intake between $\mathrm{CC}$ and NGL mice (Fig. 1). Furthermore, GH administration increased feed intake in adults, and this effect was more important in males $(P<0 \cdot 05)$ (Fig. 1).

\section{Effects of age and sex on serum lipoproteins and TAG in control chow mice}

Old CC mice (males and females) had higher TC, (LDL + VLDL)-cholesterol and TAG, and lower HDL-cholesterol levels than adult $\mathrm{CC}$ mice (males and females) $(P<0.05)$ (Fig. 2). A significant age $\times$ sex interaction was found for TC $(P<0.001)$ (Fig. 2). Old CC females and adult CC males had significantly higher TC levels than adult $\mathrm{CC}$ females $(P<0 \cdot 05)$ (Fig. 2).

\section{Effect of dietary protein on serum lipoprotein levels}

In comparison with their CC counterparts, all NGL mice (males, females, adults and old mice) displayed higher TC and (LDL + VLDL)-cholesterol $(P<0.05)$ and lower

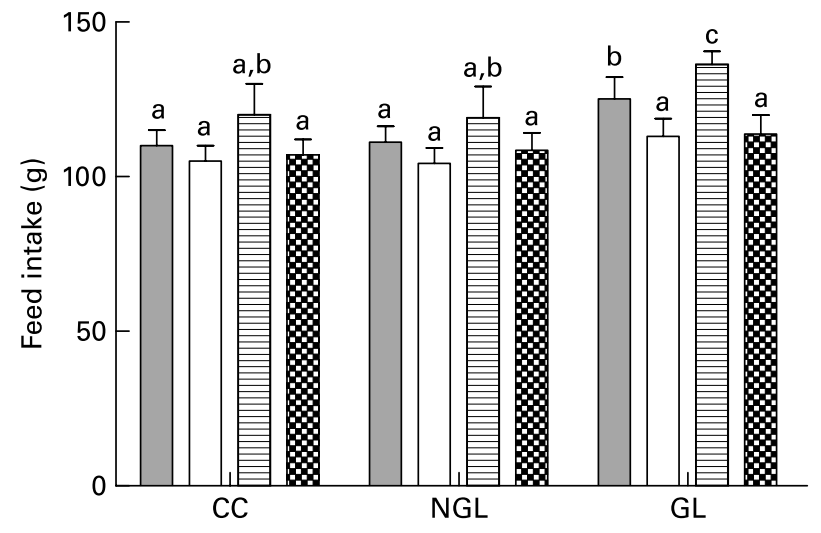

Fig. 1. Feed intake of control chow (CC), non-growth hormone lactalbumin (NGL) and growth hormone lactalbumin (GL) mice. ( $\square$ ), Adult females; ( $\square$ ), old females; (日) adult males; ( $\mathbf{B}$ ) old males. Values are means, with standard deviations represented by vertical bars. ${ }^{\text {a,b,c }}$ Mean values with unlike letters were significantly different $(P<0.05$; one-way ANOVA followed by the DMS test).
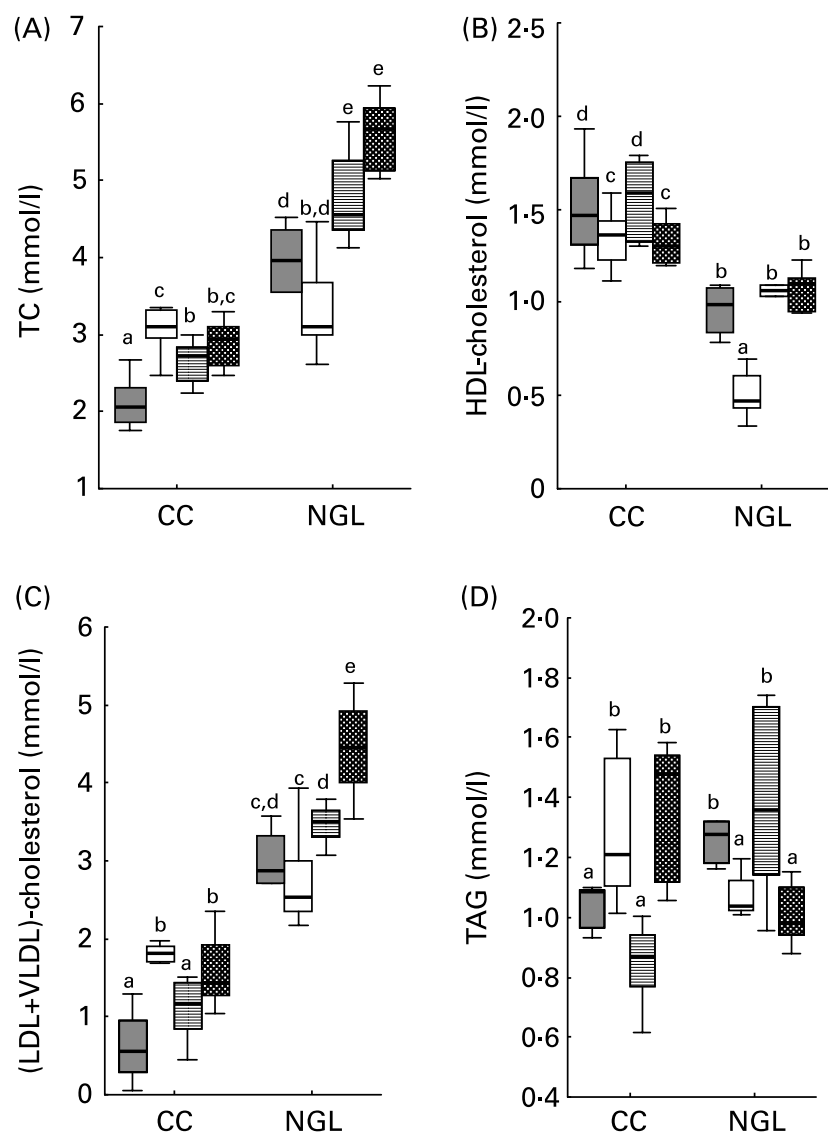

Fig. 2. Serum total cholesterol (TC) (A), HDL-cholesterol (B), (LDL + VLDL)cholesterol (C) and TAG (D) levels of control chow (CC) and non-growth hormone lactalbumin (NGL) mice. ( $\square$ ) Adult females; ( $\square$ ), old females; (日), adult males; ( $\mathbf{0}$ ), old males. Each box represents the median, and 25th and 75th percentiles; lines outside the box correspond to the maximum and minimum values of the analysed variables. ${ }^{\mathrm{a}, \mathrm{b}, \mathrm{c}, \mathrm{d}, \mathrm{e}}$ Median values with unlike letters were significantly different $(P<0.05$; one-way ANOVA followed by the DMS test and Kruskal-Wallis $\mathrm{H}$ test followed by non-parametric multiple comparisons ${ }^{(29)}$ ). For details of procedures, see Materials and methods. 
HDL-cholesterol $(P<0.05)$ levels, while adult NGL mice presented higher TAG levels $(P<0.001)$ and old NGL mice had lower TAG levels $(P<0.05)$ (Fig. 2).

Effects of age and sex on serum arylesterase activity, serum lipoprotein and body fat levels in non-growth-hormone lactalbumin mice

A significant sex $\times$ age interaction was found in NGL mice for serum TC, HDL-cholesterol, (LDL + VLDL)-cholesterol concentrations, the TC:HDL-cholesterol ratio, and quantities of gonadal and abdominal fat (Fig. 2 and Table 2). Old NGL females had significantly lower serum HDL-cholesterol $(P<0.001)$ and TAG $(P<0.05)$ concentrations and higher TC:HDL-cholesterol and (LDL + VLDL)-cholesterol:HDLcholesterol ratios $(P<0 \cdot 01)$ than adult NGL females (Fig. 2 and Table 2). Old NGL males had significantly higher serum (LDL + VLDL)-cholesterol concentrations $(P<0 \cdot 05)$, serum AE activity levels $(P<0 \cdot 01)$, AE:HDL-cholesterol ratio $(P<0.01)$, gonadal fat $(P<0.01)$ and significantly lower serum TAG $(P<0.001)$ levels than adult NGL males (Fig. 2 and Table 2). Serum AE activity was higher in adult females than in adults males $(P<0 \cdot 01)$, while the opposite was observed in old male mice, whose $\mathrm{AE}$ was higher than that of the old females $(P<0.001)$.

NGL males (adult + old) showed significantly higher serum TC, HDL-cholesterol and (LDL + VLDL)-cholesterol concentrations $(P<0.05)$, and a lower AE:HDL-cholesterol ratio (data not shown) than NGL females (adult and old), in addition to a smaller amount of abdominal and gonadal fat $(P<0.05)$. Old NGL mice (males and females) had higher AE activity levels $(P<0.01)$ and TC:HDL-cholesterol, (LDL + VLDL)-cholesterol:HDL-cholesterol, AE:HDL-cholesterol ratios $(P<0.05)$ (data not shown), and lower HDL-cholesterol $(P<0.05)$ and TAG $(P<0.001)$ concentrations than adult NGL mice.

\section{Effect of growth hormone administration on arylesterase} activity, lipoproteins-cholesterol and body fat levels

Three-way ANOVA revealed significant main effects of age, sex and treatment, as well as significant double (age $\times$ treatment, sex $\times$ treatment) and triple (age $\times$ sex $\times$ treatment) interactions for the variables studied. To clarify all these main effects and interactions, the percentage of change attributable to the effect of treatment for every group was calculated using the next expression $((\mathrm{NGL}$ mean - GL mean $) \times 100) / \mathrm{NGL}$ mean). All results are summarised in Table 3.

A triple significant age $\times \operatorname{sex} \times$ treatment interaction was found for serum TC $(P<0.05)$, ( $\mathrm{LDL}+\mathrm{VLDL})$-cholesterol $(P<0.05)$ and gonadal fat $(P<0.01)$. TC and $(\mathrm{LDL}+$ VLDL)-cholesterol levels were significantly higher in adult GL males (22 and $23 \%$, respectively) and significantly lower in old GL males (15 and $17 \%$, respectively) than in their NGL counterparts (Table 3). The amount of gonadal fat in all GL mice except adult males was significantly lower (26-75\%) than that of the NGL mice (Table 3).

A significant age $\times$ treatment interaction was found for serum HDL-cholesterol $(P<0.01)$ concentrations and abdominal fat $(P<0.05)$. GH administration resulted in significantly higher serum HDL-cholesterol concentrations $(23 \%)$ in adults and, particularly, in adult females (26\%) than in

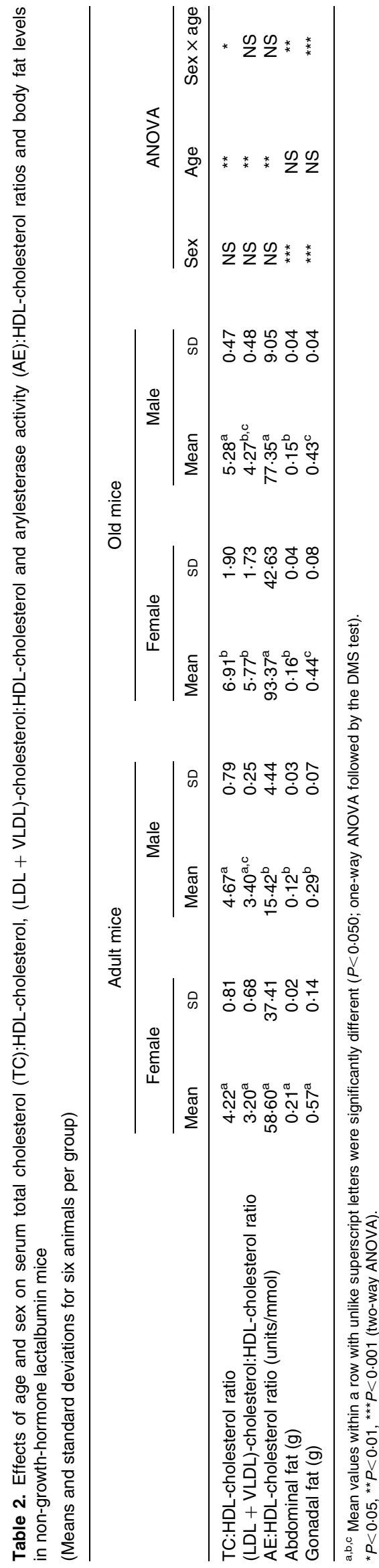


Table 3. Effects of recombinant human growth hormone treatment on serum TAG, total cholesterol (TC) and lipoprotein-cholesterol concentrations, arylesterase activity (AE), and gonadal fat (GF) and abdominal fat (AF) fat levels in growth-hormone-treated lactalbumin (GL) mice

(Mean values and standard deviations)

\begin{tabular}{|c|c|c|c|c|c|c|c|c|c|c|c|c|c|c|c|}
\hline & \multirow[b]{2}{*}{$n$} & \multicolumn{2}{|c|}{$\mathrm{TC}(\mathrm{mmol} / \mathrm{l})$} & \multicolumn{2}{|c|}{$\begin{array}{l}\text { LDL + VLDL- } \\
\text { cholesterol } \\
(\mathrm{mmol} / \mathrm{l})\end{array}$} & \multicolumn{2}{|c|}{$\begin{array}{l}\text { HDL-cholesterol } \\
(\mathrm{mmol} / \mathrm{l})\end{array}$} & \multicolumn{2}{|c|}{ TAG $(\mathrm{mmol} / \mathrm{l})$} & \multicolumn{2}{|c|}{$\mathrm{AE}$ (units/l) } & \multicolumn{2}{|c|}{ GF (g) } & \multicolumn{2}{|c|}{$\mathrm{AF}(\mathrm{g})$} \\
\hline & & Mean & SD & Mean & SD & Mean & SD & Mean & SD & Mean & SD & Mean & SD & Mean & SD \\
\hline \multicolumn{16}{|c|}{ Adult mice } \\
\hline NGL & 12 & 4.44 & 0.67 & $3 \cdot 32$ & 0.53 & $1.01 \dagger$ & 0.12 & $1.33 t$ & 0.24 & $36 \cdot 22 \dagger$ & $27 \cdot 84$ & 0.37 & 0.18 & 0.16 & 0.05 \\
\hline $\mathrm{GL}$ & 12 & 4.96 & 1.03 & 3.60 & 1.02 & 1.24 & 0.28 & 1.59 & 0.25 & 30.52 & $10 \cdot 74$ & 0.25 & 0.06 & 0.05 & 0.03 \\
\hline$\% \ddagger$ & & -12 & & -8 & & $-23^{\star}$ & & $-20^{\star \star \star}$ & & 16 & & $40^{\star \star}$ & & $61^{\star \star \star *}$ & \\
\hline \multicolumn{16}{|c|}{ Old mice } \\
\hline NGL & 12 & 4.39 & 1.28 & 3.61 & 1.06 & 0.76 & 0.31 & 1.04 & 0.09 & 63.62 & 23.93 & 0.44 & 0.07 & 0.16 & 0.04 \\
\hline $\mathrm{GL}$ & 12 & 4.00 & 0.87 & 3.23 & 0.70 & 0.76 & 0.32 & 1.24 & $0 \cdot 17$ & 38.52 & 30.41 & 0.32 & 0.07 & 0.08 & 0.03 \\
\hline$\%$ & & 9 & & 10 & & 0 & & $-18^{\star \star \star}$ & & $39^{*}$ & & $30^{\star *}$ & & $53^{\star \star \star}$ & \\
\hline \multicolumn{16}{|c|}{ Females } \\
\hline NGL & 12 & $3.66 \S$ & 0.58 & $2.93 \S$ & 0.52 & $0.71 \S$ & 0.26 & $1 \cdot 16$ & 0.11 & $50 \cdot 47$ & 24.51 & $0.51 \S$ & 0.12 & $0.18 \S$ & 0.04 \\
\hline $\mathrm{GL}$ & 12 & 3.84 & 0.87 & 2.94 & 0.74 & 0.83 & 0.40 & 1.36 & $0 \cdot 17$ & $16 \cdot 67$ & 17.96 & 0.28 & 0.09 & 0.07 & 0.03 \\
\hline$\%$ & & -5 & & 0 & & -18 & & $-17^{\star \star *}$ & & $67^{\star * *}$ & & $48^{\star \star}$ & & $59^{\star \star *}$ & \\
\hline \multicolumn{16}{|l|}{ Males } \\
\hline NGL & 12 & $5 \cdot 16$ & 0.72 & 4.06 & 0.73 & 1.07 & $0 \cdot 10$ & $1 \cdot 22$ & 0.31 & $50 \cdot 47$ & $34 \cdot 20$ & 0.31 & 0.09 & 0.14 & 0.04 \\
\hline $\mathrm{GL}$ & 12 & 5.28 & 0.66 & 4.05 & 0.59 & 1.16 & 0.28 & 1.46 & 0.37 & $49 \cdot 25$ & 18.68 & 0.30 & 0.04 & 0.06 & 0.04 \\
\hline$\%$ & & -2 & & 0 & & -8 & & $-21^{*}$ & & 2 & & 3 & & $52^{\star \star \star}$ & \\
\hline \multicolumn{16}{|c|}{ Adult females } \\
\hline NGL & 6 & $3.98^{\mathrm{a}}$ & 0.40 & $3.01^{a}$ & 0.35 & $0.96^{a}$ & 0.13 & $1 \cdot 26^{a}$ & 0.07 & $54.41^{a}$ & 29.89 & $0.57^{a}$ & 0.14 & $0.21^{a}$ & 0.02 \\
\hline $\mathrm{GL}$ & 6 & $4 \cdot 39^{a, b}$ & 0.86 & $3 \cdot 13^{a}$ & 0.85 & $1.21^{\mathrm{b}}$ & 0.26 & $1.45^{\mathrm{b}}$ & 0.08 & $22.99^{a}$ & 1.60 & $0.23^{b}$ & 0.08 & $0.07^{b}$ & 0.03 \\
\hline$\%$ & & -10 & & -4 & & $-26^{*}$ & & $-15^{\star \star \star}$ & & 58 & & $60^{\star \star}$ & & $67^{\star \star \star}$ & \\
\hline \multicolumn{16}{|c|}{ Adult males } \\
\hline NGL & 6 & $4 \cdot 78^{\mathrm{b}}$ & 0.64 & $3.59^{a, c}$ & 0.52 & $1.07^{\mathrm{a}, \mathrm{b}}$ & 0.10 & $1 \cdot 39^{a, b}$ & 0.32 & $18.04^{b}$ & $4 \cdot 30$ & $0.29^{b}$ & 0.29 & $0.12^{\mathrm{C}}$ & 0.03 \\
\hline $\mathrm{GL}$ & 6 & $5.82^{\mathrm{c}}$ & 0.63 & $4 \cdot 41^{\mathrm{b}}$ & 0.74 & $1 \cdot 27^{\mathrm{b}}$ & 0.32 & $1.81^{\mathrm{c}}$ & 0.24 & $36 \cdot 17^{\mathrm{a}}$ & $11 \cdot 29$ & $0.28^{b}$ & 0.01 & $0.03^{b}$ & 0.01 \\
\hline$\%$ & & $-22^{\star \star}$ & & $-23^{*}$ & & -19 & & $-30^{\star *}$ & & $-100^{\star \star}$ & & -3 & & $75^{\star \star \star}$ & \\
\hline \multicolumn{16}{|c|}{ Old females } \\
\hline NGL & 6 & $3 \cdot 42^{a, d}$ & 0.61 & $2 \cdot 86^{a}$ & 0.63 & $0.52^{c}$ & 0.13 & $1 \cdot 08^{d}$ & 0.07 & $47.09^{a}$ & $20 \cdot 71$ & $0.44^{c}$ & 0.08 & $0.16^{\mathrm{ac}}$ & 0.04 \\
\hline $\mathrm{GL}$ & 6 & $3 \cdot 30^{\mathrm{d}}$ & 0.47 & $2 \cdot 75^{\mathrm{a}}$ & 0.56 & $0.55^{\mathrm{c}}$ & 0.19 & $1.27^{\mathrm{a}}$ & $0 \cdot 18$ & $10 \cdot 36^{b}$ & 6.42 & $0.32^{b}$ & 0.09 & $0.07^{b}$ & 0.03 \\
\hline$\%$ & & 4 & & 4 & & -6 & & $-18^{* \star *}$ & & $78^{\star *}$ & & $27^{\star \star}$ & & $56^{\star \star \star}$ & \\
\hline \multicolumn{16}{|c|}{ Old males } \\
\hline NGL & 6 & $5 \cdot 68^{c}$ & 0.49 & $4 \cdot 60^{b}$ & 0.54 & $1.08^{a, b}$ & $0 \cdot 11$ & $0.99^{d}$ & 0.10 & $82 \cdot 90^{\mathrm{C}}$ & 5.56 & $0.43^{\mathrm{c}}$ & 0.04 & $0 \cdot 15^{c}$ & 0.04 \\
\hline $\mathrm{GL}$ & 6 & $4 \cdot 85^{\mathrm{b}}$ & 0.20 & $3 \cdot 80^{c}$ & 0.28 & $1.05^{a, b}$ & $0.0 \cdot 19$ & $1 \cdot 20^{\mathrm{a}}$ & $0 \cdot 16$ & $66 \cdot 68^{\mathrm{a}}$ & 9.59 & $0.32^{\mathrm{b}}$ & 0.04 & $0.09^{b}$ & 0.02 \\
\hline$\%$ & & $15^{\star}$ & & $17^{\star \star}$ & & 3 & & $-21^{*}$ & & $20^{*}$ & & $26^{\star \star}$ & & $40^{\star \star \star \star}$ & \\
\hline
\end{tabular}

NGL, non-growth-hormone lactalbumin.

a,b,c,d Mean values within a column with unlike superscript letters were significantly different $(P<0.05$; one-way ANOVA followed by the DMS test and Kruskal-Wallis $\mathrm{H}$ test followed by non-parametric multiple comparisons ${ }^{(29)}$.

${ }^{\star} P<0.05,{ }^{\star \star} P<0.01,{ }^{* \star *} P<0.001$ (unpaired Student's $t$ test for parametric variables and Kruskal-Wallis $\mathrm{H}$ test for TAG and AE).

$\dagger$ Significantly different from their old NGL counterparts.

$\ddagger$ Percentage change is calculated as ((NGL mean - GL mean)/NGL mean) $\times 100$

$\S$ Significantly different from their male NGL counterparts.

NGL mice (Table 3). The amount of abdominal fat in adult and old GL mice (61\% and 53\%, respectively) was significantly lower than that of NGL animals (Table 3).

A significant sex $\times$ treatment interaction was found for gonadal and abdominal fat $(P<0 \cdot 05)$. GL mice of both sexes displayed less abdominal fat than their NGL counterparts, although this was more noticeable in the females $(59 \%)$ than in the males $(52 \%)$ (Table 3). Female GL mice had lower gonadal fat (48\%) than their NGL counterparts.

AE was significantly lower in old (39\%) and female $(67 \%)$ GL mice than in NGL mice (Table 3). Compared with NGL animals, AE concentrations were significantly lower in old GL females $(78 \%)$ and males $(20 \%)$ but were higher in adult GL males $(100 \%)$ (Table 3$)$.

Serum TAG concentrations were higher (15-30\%) $(P<0.05)$ in all GL mice (Table 3). TC:HDL-cholesterol, (LDL + VLDL)-cholesterol:HDL-cholesterol and AE:HDLcholesterol ratios did not differ significantly between GL and NGL groups except in old GL male mice, whose
AE:HDL-cholesterol ratio was significantly lower $(P<0 \cdot 050)$ than that of their NGL counterparts (data not shown).

Relationships between arylesterase activity and lipid and lipoprotein-cholesterol concentrations and amount of body fat in non-growth-hormone lactalbumin and growth-hormonetreated lactalbumin mice

Table 4 shows the correlations of serum AE activity levels, serum lipid and lipoprotein-cholesterol concentrations and amounts of abdominal and gonadal fat in NGL and GL mice. Serum AE activity was positively correlated with serum TC and (LDL + VLDL)-cholesterol concentrations and negatively correlated with serum levels in all NGL animals. In adult NGL mice, serum AE activity was negatively correlated with serum TC and (LDL + VLDL)-cholesterol levels in males and positively correlated with these same levels in NGL females while in the adult GL males, AE activity only displayed a significant positive correlation with 
Table 4. Plasma arylesterase activity correlations with lipoprotein-cholesterol concentrations and body fat levels in non-growth hormone lactalbumin (NGL) and growth hormone-treated lactalbumin (GL) mice

\begin{tabular}{|c|c|c|c|c|c|}
\hline & \multirow[b]{2}{*}{$n$} & \multicolumn{2}{|c|}{ NGL } & \multicolumn{2}{|c|}{ GL } \\
\hline & & $r$ & $P$ & $r$ & $P$ \\
\hline All & 24 & & & & \\
\hline Total cholesterol $(\mathrm{mmol} / \mathrm{l})$ & & 0.31 & NS & 0.33 & * \\
\hline HDL-cholesterol (mmol/l) & & 0.15 & NS & 0.08 & NS \\
\hline (LDL+ VLDL)-cholesterol (mmol/l) & & 0.48 & * & 0.42 & ** \\
\hline $\mathrm{TAG}(\mathrm{mmol} / \mathrm{l})$ & & -0.44 & * & -0.35 & ** \\
\hline Abdominal fat $(\mathrm{g})$ & & 0.22 & NS & 0.28 & NS \\
\hline Gonadal fat $(\mathrm{g})$ & & 0.36 & NS & 0.30 & NS \\
\hline Adult males & 6 & & & & \\
\hline Total cholesterol $(\mathrm{mmol} / \mathrm{l})$ & & 0.99 & 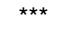 & -0.42 & NS \\
\hline HDL-cholesterol (mmol/l) & & -0.4 & NS & 0.37 & NS \\
\hline$(\mathrm{LDL}+\mathrm{VLDL})$-cholesterol $(\mathrm{mmol} / \mathrm{l})$ & & -0.99 & $\star \star * \star$ & -0.11 & NS \\
\hline TAG $(\mathrm{mmol} / \mathrm{l})$ & & -0.36 & NS & 0.75 & NS \\
\hline Abdominal fat $(\mathrm{g})$ & & -0.1 & NS & $-0 \cdot 10$ & NS \\
\hline Gonadal fat $(\mathrm{g})$ & & -0.86 & * & -0.67 & NS \\
\hline Old males & 6 & & & & \\
\hline Total cholesterol $(\mathrm{mmol} / \mathrm{l})$ & & 0.14 & NS & -0.75 & NS \\
\hline HDL-cholesterol (mmol/l) & & -0.72 & NS & 0.27 & NS \\
\hline$(\mathrm{LDL}+\mathrm{VLDL})$-cholesterol $(\mathrm{mmol} / \mathrm{l})$ & & 0.11 & NS & -0.46 & NS \\
\hline TAG $(\mathrm{mmol} / \mathrm{l})$ & & -0.36 & NS & -0.12 & NS \\
\hline Abdominal fat $(\mathrm{g})$ & & -0.11 & NS & -0.99 & *** \\
\hline Gonadal fat $(\mathrm{g})$ & & -0.83 & * & 0.99 & *** \\
\hline Adult females & 6 & & & & \\
\hline Total cholesterol $(\mathrm{mmol} / \mathrm{l})$ & & 0.91 & ** & -0.84 & * \\
\hline HDL-cholesterol (mmol/l) & & -0.26 & NS & 0.27 & NS \\
\hline$(\mathrm{LDL}+\mathrm{VLDL})$-cholesterol $(\mathrm{mmol} / \mathrm{l})$ & & 0.91 & ** & -0.21 & NS \\
\hline TAG $(\mathrm{mmol} / \mathrm{l})$ & & -0.91 & ** & -0.60 & NS \\
\hline Abdominal fat $(\mathrm{g})$ & & 0.50 & NS & 0.48 & NS \\
\hline Gonadal fat $(\mathrm{g})$ & & & NS & 0.46 & NS \\
\hline Old females & 6 & & & & \\
\hline Total cholesterol $(\mathrm{mmol} / \mathrm{l})$ & & 0.99 & *** & 0.50 & NS \\
\hline HDL-cholesterol (mmol/l) & & 0.35 & NS & $0 \cdot 19$ & NS \\
\hline$(\mathrm{LDL}+\mathrm{VLDL})$-cholesterol $(\mathrm{mmol} / \mathrm{l})$ & & 0.97 & *** & 0.80 & * \\
\hline TAG $(\mathrm{mmol} / \mathrm{l})$ & & 0.35 & NS & -0.50 & NS \\
\hline Abdominal fat $(\mathrm{g})$ & & $0 \cdot 20$ & NS & 0.22 & NS \\
\hline Gonadal fat $(\mathrm{g})$ & & 0.20 & NS & $0 \cdot 15$ & NS \\
\hline
\end{tabular}

${ }^{\star} P<0.05,{ }^{* \star} P<0.01,{ }^{* \star *} P<0.001$ (Spearman's correlation).

serum TAG levels. In adult and old NGL males, AE was also negatively correlated with gonadal fat. In adult NGL females, serum AE activity was negatively correlated with serum TAG levels. In old GL male mice, AE activity was positively correlated with gonadal fat and negatively correlated with abdominal fat. In old NGL and GL females, serum AE activity was significantly correlated with serum TC and (LDL + VLDL)cholesterol concentrations.

\section{Discussion}

TC and lipoprotein-cholesterol levels of $\mathrm{CC}$ adult mice coincide with those of other mice ${ }^{(6,31)}$ where HDL, which carried at least $60 \%$ of TC, was found to be the most abundant lipoprotein. TAG levels of $\mathrm{CC}$ adult mice concurred with those obtained by Moen et al. ${ }^{(32)}$. Moreover, as expected, lipoprotein-cholesterol and TAG levels increased in CC old mice $^{(33)}$.

The inclusion of $14 \%$ lactalbumin in the murine diet induced an atherogenic lipoprotein profile in NGL mice in comparison with their CC counterparts. Non-HDL-cholesterol concentrations in adult NGL mice were four to six times higher than those of HDL-cholesterol, similar to those reported by Le Boeuf et al. ${ }^{(34)}$ in the same strain of mice given a high-fat diet. It has been suggested that animal proteins, such as lactalbumin, promote hypercholesterolaemia and atherosclerosis, while plant proteins, such as soya proteins, with a low lysine:arginine ratio, have hypocholesterolaemic and atheroprotective properties ${ }^{(35,36)}$.

Sex and age affected the lipoprotein-cholesterol concentrations of NGL mice. Oestrogens have been known to act as antioxidants, while testosterone has been shown to inhibit lipoprotein lipase and to increase LDL-cholesterol $^{(37,38)}$, explaining, at least in part, the present results. Although, in different ways, the serum lipid profile of both NGL and CC mice worsened with age. In fact, old NGL males displayed higher (LDL + VLDL)-cholesterol concentrations than adult NGL males while old NGL females presented lower HDLcholesterol levels than adult NGL females. These sex- and age-related changes should be associated with the decrease in sex hormone levels in both old NGL males and females ${ }^{(39,40)}$. As previously indicated, reduced testosterone levels in elderly males would explain the increase in (LDL + VLDL)-cholesterol. The reduction in oestrogen concentrations 
after the menopause has been found to lower HDL-cholesterol concentrations in women ${ }^{(37)}$.

The fact that old NGL mice presented lower TAG values than adults is not easy to explain, taking into account that ageing is normally associated with high TAG levels in man $^{(21)}$. It is known that hypercholesterolaemic mice present low TAG levels ${ }^{(6)}$; thus, the decrease of TAG with age should be related to the presence of cholesterol-enriched VLDL. In fact, the present data on TC, TAG and (LDL + VLDL)-cholesterol suggest that the cholesterol content of the VLDL fraction increases in old NGL mice, producing cholesterol-enriched VLDL particles (for example, $\beta$-VLDL).

In concordance with other studies in mice ${ }^{(41)}$, adult NGL females showed higher AE activity than adult NGL males. These differences should be ascribed to their different lipoprotein profiles and body fat contents, as suggested by the data and the different significant correlations observed. However, while AE activity increased in old NGL males, it remained stable in old NGL females. Thus, the sex-related differences in AE activity observed in the adult NGL mice were inverted with ageing. These findings coincide with recent results in rats ${ }^{(42)}$. The explanation for this age-sex interaction on $\mathrm{AE}$ activity may be that AE activity is constant in old NGL females despite reduced HDL-cholesterol levels. Thus, VLDL-cholesterol may stabilise paraoxonase 1 activity, as proposed by Deakin et al. ${ }^{(43)}$. This hypothesis is supported by the strong positive correlation found in the present study between $\mathrm{AE}$ and (VLDL + LDL)-cholesterol in old NGL females. Therefore, as Thomás-Moyá et al. ${ }^{(42)}$ suggest, and the negative correlation between AE activity and (VLDL + LDL)-cholesterol in these animals supports, the increase in AE activity in old NGL males may be due to a mechanism designed to counterbalance the age-related increase in (VLDL + LDL)-cholesterol concentrations.

The AE:HDL-cholesterol ratio should be considered an indicator of the antioxidant potential of HDL. In fact, adult NGL mice had lower ratios than old NGL mice, and NGL females had higher ratios than NGL males, suggesting a powerful age- and sex-related response against peroxidation.

The present results show for the first time that GH administration in mice interacts with age and sex hormones, resulting in different effects on lipids, lipoproteins and $\mathrm{AE}$ in young and old and male and female mice with an atherogenic lipid profile induced by lactalbumin. In contradiction to the findings of other trials ${ }^{(8)}$, the effects of GH on TC, (LDL + VLDL)-cholesterol and gonadal fat were age and sex dependent. These effects were in general more important in males than in females, probably due to the negative modulating effect of oestrogens on $\mathrm{GH}$ action $^{(44)}$. Furthermore, in accordance with other studies ${ }^{(8,45,46)}$, the present results demonstrate that exogenous GH administration improved the atherogenic profile of old GL males, while it worsened the lipoprotein profile of adult GL males.

Contradictory results have been published regarding the effect of GH on HDL metabolism, including both a decrease $^{(45)}$ and an increase in HDL-cholesterol levels ${ }^{(46)}$. Nevertheless, the present results on HDL-cholesterol coincide with those of Bänsch et al. ${ }^{(37)}$, who found a positive correlation between GH and HDL-cholesterol concentrations in healthy women but not in men. Bänsch et al. ${ }^{(37)}$ found that synergy exists between $\mathrm{GH}$ and oestrogens with regard to the regulation of HDL metabolism, explaining why levels of
HDL-cholesterol in the present study increased only in adult and not in old GL female mice.

To the best of our knowledge, this is the first time that AE activity has been related to body fat content. The strong negative correlation found between AE activity and gonadal fat in NGL adult and old male mice is very interesting. At present, we have no clear hypothesis to explain these results, which are probably related to the high (LDL + VLDL)-C levels and the binding of $\mathrm{AE}$ to the VLDL fraction ${ }^{(43)}$. A large gonadal fat deposit has previously been related to high VLDL concentrations in mice ${ }^{(44)}$. Furthermore, since administration of GH is known to affect abdominal fat first ${ }^{(12)}$, the strong negative correlation observed between $\mathrm{AE}$ activity and abdominal fat in old GL males suggests that AE could represent a new marker of adiposity in old GL male mice.

The reduction in abdominal and gonadal fats in old GL mice concurred with results previously described in rats and human subjects $^{(47)}$ and may be related to the parallel decrease of AE activity in these animals, and could also be due to reduced lipid peroxidation, as previously demonstrated in old Wistar rats ${ }^{(48)}$. GL females displayed low AE activity and these females also displayed the lowest amount of abdominal fat. Thus, we conclude that differences regarding AE activity between the sexes in both NGL and GL mice were related to differences in body fat levels.

Noteworthy is the observation of the diminution of body fat levels due to $\mathrm{GH}$ administration despite the increase in feed intake. Previous studies have demonstrated that the effect of $\mathrm{GH}$ on food intake is species, age and sex dependent ${ }^{(49,50)}$. Our own study shows that GH administration diminished body fat levels in all animals independently of age and sex, and paradoxically there was an increased feed intake in adult mice and to a greater magnitude in males than in females, suggesting important effects of sex and ageing hormone regulation. One interpretation of this finding is that the lowering of adipocyte critical mass due to $\mathrm{GH}$ administration would be expected to affect negatively the production of leptin ${ }^{(50)}$ and in turn induce an increase in food intake.

In short, the results of the present study suggest that the effects of GH on some CVD markers are highly dependent on age and sex. Old male mice seem to be the target for GH treatment, which improves the lipoprotein profile and decreases abdominal and gonadal fat. AE activity in mice diminished as a consequence of improved antioxidant status, as we reported previously in human subjects ${ }^{(23)}$. These results also suggest that $\mathrm{GH}$ therapy would be more effective in aged men.

\section{Acknowledgements}

The present study was supported by the Project AGL 20012398-C03-03 and AGL 2005-07204-C02-01/ALI of the Spanish Ministerio de Educación y Ciencia and the Project PR41/06-14972 of Universidad Complutense and Banco de Santander. We also thank the Universidad Complutense for the grant for M. N.

E. L.-O. and M. N. should be considered as the first author. E. L.-O., A. A.-T. and W. V. took care of the animals and determined lipoproteins, TC and TAG, and helped in the data analysis. M. N. determined AE activity and analysed and discussed all results. J. M. S.-M., E. M.-M. and F. J. S.-M. supervised 
and led all experiments and the analysis and discussion of all data.

The authors declare that there is no conflict of interest.

\section{References}

1. Kritchevsky D, Tepper SA \& Klurfeld DM (1987) Cholesterol and dietary protein. J Am Oil Chem Soc 64, 1167-1171.

2. Herzberg GR \& Rogerson M (1984) Hepatic lipogenesis in young rats given proteins of different quality. $B r J$ Nutr 52, $131-137$.

3. Kritchevsky D, Tepper SA, Czarnecki SK, Story JA \& Marsh JB (1982) Experimental atherosclerosis in rabbits fed cholesterolfree diets. 11. Corn protein, wheat gluten, and lactalbumin. Nutr Rep Int 26, 931.

4. Lu YF \& Jian MR (1997) Effects of soy protein and casein on lipid metabolism in mature and suckling rats. Nutr Res 17, $1341-1350$.

5. Ni W, Tsuda $\mathrm{Y}$, Takashima $\mathrm{S}$, Sato $\mathrm{H}$, Sato $\mathrm{M} \&$ Imaizumi $\mathrm{K}$ (2003) Anti-atherogenic effect of soya and rice-protein isolate compared with casein in apolipoprotein E-deficient mice. $\mathrm{Br} J$ Nutr 90, 13-20.

6. Paigen B, Holmes PA, Mitchell D \& Albee D (1987) Comparison of atherosclerotic lesions and HDL lipid levels in male, female and testosterone-treated female mice from strains C57BL/6, BALB/c, and C.H. Atherosclerosis 64, 215-221.

7. Matasconi M, Parini P, Angelin B \& Rudling M (2005) Pituitary control of cholesterol metabolism in normal and LDL-receptor knock-out mice: effect of hypophysectomy and growth hormone treatment. Biochim Biophys Acta 1763, 221-227.

8. Laursen T (2004) Clinical pharmacological aspects of growth hormone administration. Growth Horm IGF Res 14, 16-44.

9. Frick F, Bohlooly M, Linde D, Olsson B, Tornell J, Eden S \& Oscarsson J (2001) Long term growth hormone excess induces marked alterations in lipoprotein metabolism in mice. Am J Physiol Endocrinol Metab 281, 1230-1239.

10. Bartke A (2005) Minireview: role of growth hormone/insulinlike growth factor system in mammalian aging. Endocrinology 146, 3718-3723.

11. Calle EE, Thun MJ, Petrelli JM, Rodríguez C \& Heath CW Jr (1999) Body mass index and mortality in a prospective cohort of US adults. $N$ Eng $J$ Med 341, 1097-1105.

12. Münzer T, Harman SM, Hees P, et al. (2001) Effects of GH and/ or sex steroid administration on abdominal, subcutaneous and visceral fat in healthy aged women and men. J Clin Endocrinol Metab 86, 3604-3610.

13. Agis-Torres A, López-Oliva ME, Unzaga MT \& Muñoz-Martínez E (2002) Body growth and substrate partitioning for fat and protein gain in weaned $\mathrm{BALB} / \mathrm{c}$ mice treated with growth hormone. Comp Biochem Physiol 132, 247-256.

14. Takahashi S \& Satozawa N (2002) The $20 \mathrm{kD}$ human growth hormona reduces body fat by increasing lipolysis and decreasing lipoprotein lipase activity. Horm Res 58, 157-164.

15. Angelopoulos TJ, Seip RL \& Cole TG (1998) Effect of shortterm recombinant growth hormone administration on plasma lipoproteins in elderly adults. Gerontology 44, 228-231.

16. Steen Hansen P, Kassem M, Brixen K, Klausen IC, Mosekilde L \& Faergeman O (1995) Effect of short-term recombinant growth hormone administration on lipids and lipoproteins in women and men without growth hormone disturbances. Metabolism 44, 725-729.

17. Blackmann MR, Sorkin JD, Münzer T, et al. (2002) Growth hormone and sex steroid administration in healthy aged women and men. JAMA 288, 2282-2292.

18. Yu BP \& Chung HY (2006) Adaptative mechanisms to oxidative stress during aging. Mech Ageing Dev 127, 436-443.
19. Kokoszko A, Karbownik M \& Lewinski A (2006) Increased lipid peroxidation in growth hormone-deficient adult patients. Neuro Endocrinol Lett 27, 225-230.

20. Andersson IJL, Johansson M, Wickmann A, et al. (2006) Endothelial dysfunction in growth hormone transgenic mice. Clin Sci 110, 217-225.

21. Aronow WS (2004) Lipids and the elderly. Rev Endocr Metab Disord 5, 359-364.

22. Bub A, Barth SW, Watzl B, Briviba K \& Rechkemmer G (2005) Paraoxonase 1 Q192R (PON1-192) polymorphism is associated with reduced lipid peroxidation in healthy young men on a lowcarotenoid diet supplemented with tomato juice. Br J Nutr $\mathbf{9 3}$, 291-297.

23. Nus M, Francés F, Librelotto J, Canales A, Corella D, SánchezMontero JM \& Sánchez-Muniz FJ (2007) Arylesterase activity and antioxidant status depend on PON1-Q192R and PON1L55M polymorphisms in subjects with increased risk of cardiovascular disease consuming walnut-enriched meat. J Nutr 137, $1783-1788$.

24. Olsson B, Bohlooly Y-M, Brusehed O, Isaksson OG, Ahrén B, Olofsson SO, Oscarsson J \& Törnell J (2003) Bovine growthhormone transgenic mice have major alterations in hepatic expression of metabolic genes. Am J Physiol Endocrinol Metab 285, E504-E511.

25. Spanish Royal Decree 223/88 (1988) Sobre Protección de los Animales Utilizados Para Experimentación y Otros Fines Científicos (Protection of the Animals used for Scientific Experimentation). Bol Of Estado Gac Madr Spain 67, 8509-8511.

26. Reeves PG, Nielsen FH \& Fahey GC (1993) AIN-93 purified diet for laboratory rodents: final report of the American Institute of Nutrition ad hoc writing committee on the reformulation of the AIN-76A rodent diet. J Nutr 123, 1939-1951.

27. Nus M, Sánchez-Muniz FJ \& Sánchez-Montero JM (2006) A new method for the determination of arylesterase activity in human serum using simulated body fluid. Atherosclerosis $\mathbf{1 8 8}$, $155-159$.

28. Nus M, Sánchez-Muniz FJ, Sinisterra Gago JV, López-Oliva E \& Sánchez-Montero JM (2008) Determination of rat and mice arylesterase activity using serum mimetics. Enz Microb Technol (Epublication ahead of print version 13 May 2008).

29. Sánchez M, Frutos G \& Cuesta PL (1996) Estadística y Matemáticas Aplicadas (Applied Statistics and Mathematics). Madrid: Ed. Síntesis.

30. Bardsley WG (2004) SIMFIT 5.4, A Computer Package for Simulation, Curve Fitting Statistical Analysis in the Life Sciences. Manchester, UK: Manchester University.

31. Terpstra AHM, Sánchez-Muniz FJ, West CE \& Woodward CJH (1982) The density profile and cholesterol concentration of serum lipoproteins in domestic and laboratory animals. Comp Biochem Physiol B 71, 669-763.

32. Moen CJA, Tholens AP, Voshol PJ, de Haan W, Havekes LM, Gargalovic P, Lusis AJ, van Dyck KW, Frants RR, Hofker MH \& Rensen PCN (2007) The Hyplip2 locus causes hypertriglyceridemia by decreased clearance of triglycerides. J Lipid Res $\mathbf{4 8}$, 2182-2192.

33. Orlandi A, Bochaton-Piallat ML, Gabbiani G \& Spagnoli LG (2006) Aging, smooth muscle cells and vascular pathobiology: implications for atherosclerosis. Atherosclerosis $\mathbf{1 8 8}$, 221-230.

34. Le Boeuf RC, Doolittle MH, Montcalm A, Martin DC, Reue K \& Lusis AJ (1990) Phenotypic characterization of the Ath-1 gene controlling high density lipoprotein levels and susceptibility to atherosclerosis. J Lipid Res 31, 91-101.

35. Vázquez J \& Sánchez-Muniz FJ (1994) Revisión: proteína de pescado y metabolismo del colesterol (Revision: fish protein and metabolism of cholesterol). Rev Esp Cien Tecnol Alim 34, 589-608. 
36. Terpstra AH \& Sánchez-Muniz FJ (1981) Time course of the development of hypercholesterolemia in rabbits fed semipurified diets containing casein or soybean protein. Atherosclerosis 39, 217-227.

37. Bänsch D, Dirkes-Kersting A, Schulte H, Assmann G \& von Eckardstein A (1997) Basal growth hormone levels are positively correlated with high density lipoprotein cholesterol levels in women. Metabolism 46, 1039-1043.

38. De Pergola G (2000) The adipose tissue metabolism: role of testosterone and dehydroepiandrosterone. Int J Obes Relat Metab Disord 24, 59-63.

39. Montalcini T, Emanuele V, Gorgone G, et al. (2003) Influence of endogenous sex hormones on carotid atherosclerosis in postmenopausal women. Nutr Metab Cardiovasc Dis 13, 334.

40. Muller M, van den Beld AW, Bots ML, Grobbee DE, Lamberts SWJ \& van der Schouw YT (2004) Endogenous sex hormones and progression of carotid atherosclerosis in elderly men. Circulation 109, 2074-2079.

41. Bin Ali A, Zhang Q, Koon Lim Y, Fang D, Retnam L \& Lim SK (2003) Expression of major HDL-associated antioxidant PON-1 is sex dependent and regulated during inflammation. Free Rad Biol Med 34, 824-829.

42. Thomás-Moyá E, Gianotti M, Proenza AM \& Lladó I (2006) The age-related paraoxonase 1 response is altered by longterm caloric restriction in male and female rats. J Lipid Res 47, 2042-2048.
43. Deakin S, Moren X \& James RW (2005) Very low density lipoproteins provide a vector for secretion of paraoxonase-1 from cells. Atherosclerosis 179, 17-25.

44. Yamazaki T, Ssaki E, Kakinuma C, Yano T, Miura S \& Ezaki O (2005) Increased very low density lipoprotein secretion and gonadal fat mass in mice overexpressing liver DGAT1. J Biol Chem 280, 21506-21514.

45. White RM, Schaefer EJ \& Papadopoulos NM (1983) The effect of growth hormone administration on lipid and lipoproteins in grow hormone deficient patients. Proc Soc Exp Biol Med 173, 63-67.

46. Garry P, Collins P \& Devlin JG (1996) An open 36 month study of lipid changes following replacement of growth hormone in acquired growth hormone deficiency. Eur J Endocrinol 134, $61-66$.

47. Malmloff K, Johansen T \& Pedersen SB (2002) Growth hormone affects both adiposity and voluntary food intake in old and obese female rats. Eur J Endocrinol 146, 121-128.

48. Castillo C, Salazar V, Ariznavarreta C, Vara E \& Tresguerres JAF (2004) Effect of recombinant human growth hormone on age-related hepatocyte changes in old male and female Wistar rats. Endocrine 25, 33-39.

49. Wang X, Day JR, Zhou Y, Beard JL \& Vasilatos-Younken R (2000) Evidence of a role for neuropeptide $Y$ and monoamines in mediating the appetite-suppresive effect of GH. $J$ Endocrinol 166, 621-630.

50. Lissett CA, Clayton PE \& Shalet SM (2001) The acute leptin response to GH. J Clin Endocr Metab 86, 4412-4415. 